\title{
Archaeology of Us and the Local Identity An Interdisciplinary Context ${ }^{*}$
}

In recent years I have coordinated several research projects focusing on places and events in comparatively recent history ${ }^{\mathrm{I}}$, as covered by the scientific field referred to as the archaeology of the contemporary past (Buchli, Lucas 2001a: 5-8; 2001b). In the case of one of these projects, which involving research in the Polish Jurassic Highland, one aim of the scientific activity has become the diagnosis of the research methods applied (Krupa-Ławrynowicz, Ławrynowicz 2016; Ławrynowicz 2016; Wejland 2016a; 2016b; 2016c). To put it very briefly, the project involves

* This paper was presented under the title "Polish Archaeology of the Postwar Period in the European Context: an Attempt to Assess Research Experiences" during the Conference of Committee for Pre- and Protohistory of the Polish Academy of Sciences, organised as part of yearly meetings "Archaeology and Society: New Research Fields and Challenges" on June 26, 2019, at the seat of the Institute of Archaeology and Ethnology PAS in Warsaw.

I The most important was the research into Nazi places in the Natolin Forest near Warsaw in 20I0, in the Okręglik Forest, and in the Lućmierz Forest near Łódź, conducted from $201 \mathrm{I}$ to 2017 together with the Institute of Archaeology of the University of Łódź and the Łódź Branch of the Scientific Association of Polish Archaeologists; research project Monopol Wódczany in Eódź. The Place and People, carried out in 2014-2017 under the cooperation agreement between the Faculty of Philosophy and History of the University of Łódź and Virako Sp. z o.o.; research project Places of Remembrance and Oblivion. Interdisciplinary Research of the Northern Part of the Polish Jurassic Highland under the National Programme for the Development of Humanities run by the Ministry of Science and Higher Education in 20I4-20I9; research project Muszyna - Plaveč: We Discover the Forgotten History and Culture of the Borderland Between Poland and Slovakia conducted in 2018 under the agreement between the Muszyna Town and Health-Resort Commune and the Faculty of Philosophy and History of the University of Łódź, being a part of the microproject Muszyna - Plaveč: We Discover the Forgotten History and Culture of the Borderland Between Poland and Slovakia (European Regional Development Fund's Interreg V-A Programme Poland - Slovakia 20I4-2020); research programme Former Gestapo and Provincial Security Department Headquarters in Anstadta Avenue in Eódź. The interdisciplinary research of a pla$c e$ was carried out in 2019 under the cooperation agreement between the University of Łódź, Łódź Special Economic Zone, and the Institute of National Remembrance. 
interdisciplinary research into places of remembrance and places of oblivion in the landscape of the northern Jurassic Highland. Based on many years of research, I would like to share a few reflections, which to some extent can be of universal significance to the archaeological study of the contemporary past.

I mostly noticed that the term that probably best conveys the meaning of archaeology of the contemporary past is archaeology of us, which is most broadly defined as research into the relationships between the contemporary society and its own material heritage (Modern Material Culture... 198I; GonzálezRuibal 20I4). In research practice, this definition should be referred to specific heritage and a specific community or even an individual connected with it (Holtorf 20I4; Kobiałka 20I7), being its more or less conscious custodian. Thus, what matters in this case, apart from the contemporary aspect, is the local aspect. Archaeology of us is thus an archaeology of specific people and communities living in a definable physical area in the present (here and now). This is very well described by the Polish term archaeology of the contemporary past (archeologia wspótczesności) as it is archaeology of shared (community - wspólnota) experience of the surrounding (more or less local) reality. Relics of this process include material traces of the existence of a given community in a certain area, and its members' remembrance of it. It is biographical, family or, more generally, local memory.

Despite numerous attempts to limit archaeology of the contemporary past to chronological ranges ending in the present time (Zalewska 20I6a: 22-23), it seems most appropriate to define this field as archaeology concerning the remembered, or post-remembered, past, meaning a field within which knowledge of the past does not only come from secondary sources: school education, research papers, media etc. (Harrison, Schofield 2010).

Knowledge of a shared recent past is constantly brought up, recalled, processed, and distorted within the local discourse. It becomes a factor describing and constituting the local identity, which consists of shared time and physical space, including places in it, together forming a unique, local cultural landscape: a common heritage (Wejland 20I6a: 40-4I). In order to identify elements of material culture that can become research objects of archaeology of the contemporary past, one has to determine what is common and significant to a given community, and what constitutes and maintains a given local community. In other words: to determine the rhythm of events and activities binding the local community together to which the local physical space functioned.

The most general rhythm of continuity and change is imposed on the local community by the shared experience of everyday life, which, in a context, is often expressed by such words as 'once' and 'today'. This is how one describes 
home, work, religious practices, education, consumption, free time, and more personal experiences, such as family and social celebrations, and overcome life challenges, as well as happy and sad events. A great value is attached to places connected with unresolved (mysterious, heroic, exceptional, difficult, complex, unwanted) past, which is related to such tragic events and processes as natural disasters (traces of fires, floods), epidemics (e.g. cholera cemeteries), and disasters (sites of communications and construction disasters). There is also a special public reception of and fascination with criminal events (such as murder traces, hidden burial places) examined by forensic archaeology (Archeologia sadowa... 20I3). One shared and often unresolved traumatic past the time of war, which is the domain of archaeology of contemporary armed conflicts (Saunders 2007; Moshenska 2013; Zalewska 20I6b) and the related past of occupation and oppression by totalitarian systems, in the case of which studies into material relics can be called the archaeology of totalitarianism (Archeologia totalitaryz$m u \ldots$ 2015). The spatial expression of war heritage is the landscape of conflict (archaeology of conflict), frequently completely unexplored by historical research (Shackel 2003; Matériel Culture... 2012; Ławrynowicz 2016: 92).

From an archaeological perspective, research into the present stands out on account of the necessity to employ broad methods of field research. This mostly results from the fact that we know 'quite a lot' about contemporary times from other sources, including our personal experience. We do not have to apply archaeological methods to obtain general data or look for the answer to the question 'How was it in the past?', which we would like to ask when examining, for example, a prehistoric burial ground. Usually, the most interesting thing is the location of the examined site (analysis of archival aerial photographs, remote sensing and geotechnical methods), and once we have decided what we want to explore, we settle for what can be seen, and for this purpose we only need non-invasive surface survey and inventorying methods, frequently limited to good photographic or video documentation (see Kobiałka 20I6). If we decide to carry out excavations, in most cases they are limited to probe drilling, unless the research project concerns pre-investment rescue surveys or large-scale exhumation operations.

Another characteristic of excavations of relatively recent archaeological structures might be the necessity to separate discovered relics of objects considered to be historic from popular products, treated as contemporary waste. While all discovered objects should be included in the archaeological documentation, only some of them, those directly connected with the object examined or exceptional for other reasons, are inventoried and included in the historic material. In the case of mass objects (artefacts), it is suggested to collect and preserve a sample 
of them. Despite its arbitrariness, such a procedure corresponds well with the subjective character of humanist research and the paradigm of pragmatism of archaeological field research, which is necessary due to such factors as limited storage space for museum collections. A unique characteristic of archaeology of the contemporary past is usually the possibility of analysing the historical material obtained during research more broadly than in the case of studies concerning earlier periods (cf. Rathje 1984; Rathje, Murphy 200I; Krupa-Ławrynowicz, Ławrynowicz 20I2). The reason for this is a relatively less advanced post-depositional process, meaning, for example, the biochemical decomposition of organic matter ${ }^{2}$. This mostly concerns textile, leather, wooden and paper artefacts. Particularly the last type might prove significant for identifying bone remains discovered together with documents allowing to identify the person buried and to determine the time and manner of death. Thus, in the case of archaeology of the contemporary past, I would call for a departure from the conservation doctrine, which is justified with regard to earlier periods, but requires minimisation of research using the excavation method.

In the archaeology of the contemporary past, archaeological research (non-invasive and excavation) concerns relatively new structures (movable and fixed), which have just gone out of use or have changed their original purpose. On the one hand these structures and artefacts are only at the initial stage of archaeologisation, but on the other hand, due to their recent age, they are usually not protected (listed as historic monuments), which makes them particularly prone to being destroyed by man (construction investments, amateur treasure hunters, acts of vandalism, lack of fire protection etc.). There is huge academic subfield that studies ruins and how the remains of abandoned industrial buildings in particular fall apart and decay (Edensor 2005). In this situation, it is important to register or, ideally, to inventory the preserved historic structures, securing the present information about the objects before they get destroyed any further or potential archaeological research is carried out at an undefined time in the near future. Some analogy can be drawn between written and iconographic sources from earlier periods, which offer a high degree of reliability, such as Erik Dahlbergh's drawings documenting the appearance of Polish cities and towns during the Swedish Deluge in 1656 before they were destroyed (Pufendorf I696) and paintings of Warsaw by Bernardo Bellotto, called Canaletto, from the I770s and the I780s.

What matters greatly in the work of an archaeologist, is its social and community dimension. Over the last few years, this has resulted in the emergence

2 When excavating twentieth-century structures connected with military activity, it is important to exercise extreme caution due to the possibility of encountering buried explosives. 
of a field called public or community archaeology (Places in Mind... 2004; Tully 2007; Zalewska 20I4a; 20I4b; Pawleta 2016). Involvement of the local community in joint activities aimed at getting to know and protecting archaeological heritage is particularly important to archaeology of the contemporary past. The contemporary past is a field of interest to amateur treasure hunters, which is why there is frequently a race against time, and more and more often why archaeologists come too late. However, archaeological research into the contemporary past, which is shared, and so relatively well-known to the society, carries a strong community overtone, reinforced by the media interest. This interest is closely followed by specific expectations of potential research sponsors, such as local politicians and company presidents, who would like to play the role of patrons of discoveries and get appreciated by their voters, customers, and business partners. Naturally, such problems also arise with regard to earlier periods, however, the contemporary past is less neutral in terms of emotions and worldview, particularly when it is connected with the memory of war, occupation and totalitarian repression (cf. Kajda 2016). A special place is occupied here by searches for postwar victims of Stalinist crime in Poland; one can get an impression that there is some competition for 'archaeological patriotism' between private foundations and the Institute of National Remembrance, which resembles the nineteenth-century search for relics of ancient cultures in the Mediterranean area and in the Middle East. When I studied the former Gestapo (1939-1945) and the communist Security Department (1945-1956) Headquarters in Lodz, the first question that I was asked by a television journalist who interviewed me was: 'What are you looking for?'. I protested and said that we were not looking for anything, but conducting research. Archaeologists, regardless of the period they deal with, cannot become hostages to the expectation of finding something. This is particularly important when it comes to research aimed at locating unmarked graves of victims of totalitarian repression, often hidden in hectares of forested land. It is important for the 'search' to methodically exclude area after area, so that research can be continued in the future.

Archaeology of the contemporary past should be perceived as a part of historical archaeology, which uses three basic types of sources: archaeological, written and iconographic (cf. Kajzer 1996; 20I3). As technologies develop, over the last decades these sources have been extended thanks to such inventions as photography, film, and the Internet. However, the greatest difference between classically defined historical archaeology and the archaeology of the contemporary past lies in the fact that the latter can use another category of sources, meaning oral sources. Some of them, just like a great majority of written 
and iconographic sources, are secondary sources. In oral tradition, secondary sources include sound recordings of, for example, memories, produced in the past as part of radio broadcasts or documentaries. One can also classify interview reports, drawn up during prosecutor's investigations and court trials, as secondary oral sources.

I believe that prompted sources are of particular significance to archaeology of the contemporary past, virtually constituting this field. If we analysed the history of any research into an archaeological site with chronology going back to a past that, from the point of view of the researcher, is contemporary past, it would turn out that the researcher used, to a greater or smaller extent, sources they prompted. In most cases, these are intuitive activities in the form of asking around among the inhabitants of the area near the research site or witnesses to the events the site is connected with. Sometimes, there are more formalised forms, such as calls for witnesses or sending out questionnaires. However, oral sources are usually prompted, obtained and analysed ad hoc, without following any procedure of professional ethnographic research (qualitative research). The interviewees are not selected, no proper interview conditions are ensured (meetings with the interviewee), no well-thought-out strategy of a qualitative interview is adopted, no recording devices are used, there are no professional transcriptions of the recordings or analyses of the interview recorded, and there are no repeat interviews in order to clear up doubts or meet with a group of interviewees to confront contradicting stories. On the other hand, applying ethnographic methods - or, in this case, simply ethnoarchaeology (cf. Prinke 1973; Kobyliński 20I2) - which consist in obtaining and analysing oral sources in a proper way, can speed up the process of locating the searched object and prevent unnecessary time- and cost-consuming field research, including excavations. Ethnoarchaeological research can be thus treated as a method of non-invasive research, minimising the potential destruction of archaeological sources.

The research in the Polish Jurassic Highland, which I mentioned at the beginning, involved archaeological and ethnographic analysis of more than 200 locations and showed how ethnoarchaeology can extend knowledge of archaeological objects. Thanks to professional ethnographic interviews, archaeological findings concerning the location, chronology, form, structure, and function of an object as well as the possibility of reconstructing it get enriched with information about the shared or individual knowledge of the location, its past, former and present significance of the place, sources of knowledge of it among members of the local community as well as stories, legends and experiences concerning it. 
An example I most frequently provide is the study of a forest grave located near Kontantynów in the Lelów Commune ${ }^{3}$, carried out in 2016 (KrupaŁawrynowicz, Ławrynowicz 20I7). It perfectly shows the complementary character of ethnoarchaeology applied to archaeology of the contemporary past. We learnt about this place from ethnographic interviews conducted with the inhabitants of the village, who said that there was a German soldier in his twenties buried there. They said he got to Konstantynów in January 1945, fleeing from the Soviet army.

In the place indicated, we found a human skeleton arranged anatomically. Large parts of the skull and phalanx bones of the left foot were missing, and there was a piece of clothing near the left foot. Examination did not reveal any dating evidence, such as documents, coins or cartridge cases with numbers. Thanks to research within the field of physical anthropology ${ }^{4}$, it was established that it was a skeleton of a male aged 25-35 years. It was also estimated that the height of the man when he was alive was $175 \mathrm{~cm}$. The researchers drew attention to healthy teeth, which had been carefully brushed and had fillings. This can be treated as an indication that the buried man had a relatively high social status. According to the forensic expert, the skeleton was damaged peri-mortem: there were many skull bone fractures. Their nature suggests that they could have been caused by gunshots, even though no entrance or exit wounds were found in the fragments preserved. Also a fracture of the left radius was identified. Based on the remains preserved, it was concluded that the probable cause of death of the man, was a central nervous system injury caused by gunshot.

By combining archaeological research with analyses conducted by a physical anthropologist, we were able to conclude that a few decades ago - which was indicated by the soft tissue decay and bone mineralisation - a young man was buried in a roadside, forest grave. The deceased died of a gunshot wound, and his left forearm had been broken, probably before his death. The almost complete lack of textile or leather fragments in the grave indicated that the body had been undressed prior to burial. It can be assumed that before burial the corpse was left exposed to weather conditions and forest animals; the

3 The grave is located in the immediate vicinity of the village of Konstantynow in the Lelów Commune, but this already is the Konstantynów Forest District (Złoty Potok Forest Division), which, in turn, is located in the Janów Commune. For formal reasons, the archaeological research site was called 'Konstantynów-Forest, Janów Commune'.

4 W. Lorkiewcz, Analiza antropologiczna szkieletu ludzkiego odkrytego na stanowisku I, Konstantynów-Las, gm. Janów, Łódź 20I7; a manuscript in the archive of the Institute of Archaeology of the University of Łódź. 
phalanx bones of the left foot, where missing and which it seems likely that they were bitten off by a wild animal, such as a fox.

The presence of gunshot wounds and the general appearance of the skeletal remains suggested that the burial was comparatively recent and most likely dated to the Second World War or period of Communist repression. Based on the fact that the body had not been exhumed and moved to the local cemetery, it could be inferred that the dead man had not been the village inhabitant. Considering knowledge of similar graves near Lelów and Janów, i.e. using the regional historical context, it seemed most probable that the dead man had been a German or Polish soldier killed during the Second World War. It seemed less probable that it was a single grave of a Soviet soldier who had died in 1945 as such graves had been exhumed soon after the war. At first, the grave in question had a rectangular mound and a wooden cross. There were a few burnt-out lights there, which suggested that the grave was sometimes visited.

The grave in the outskirts of the village of Konstantynów is an example of a place unexplored by historical research. The amount of information obtained through archaeological studies of a grave mostly depends on the dead person's belongings buried with him and the state of preservation of these belongings. When studying recent archaeological remains, which include structures from the Second World War, there is a chance of finding not only metal items, such as dog tags, rings, coins, and buttons, but also textile and leather elements of clothing, or even things made of cardboard and paper, e.g. identity documents, calendars, diaries etc. If the grave pit holds no such items, archaeologists are not able to verify whether the discovered remains are the remains of a Pole or a German, a soldier or a civilian. They are forced to draw conclusions based on the analysis of the location and structure of the grave, and on research in the field of physical anthropology. In this particular case, the only source of information about the dead man's identity and circumstances of his death could be the accounts of the inhabitants of Konstantynów. Ethnographic interviews confirmed and, to a large extent, supplemented our knowledge of the grave discovered. People said that a German military veterinarian in his twenties, a husband and a father of two children, was buried there. He stayed in the area in the middle of January 1945 . He had come by car with another soldier, who might have been Czech, but they were both soon captured by the soldiers of the entering Red Army. The Czech was released, while the German, wounded in the leg, was kept in one of the houses, and then killed in front of the local inhabitants' eyes. The body of the shot German was buried in 
the forest by one of the inhabitants. As the ground was frozen - being was January - the grave was shallow, which probably explains the fact that a part of one foot was bitten off by an animal. Later, on the initiative of a forester, the body was exhumed and buried in a place that the local community still takes care of.

Ethnographic research making use of collective memory explained the lack of clothes and personal belongings in the grave. It turned out that they had been taken by one of inhabitants right after the man had been killed. Thus, ethnographic interviews allowed us to confirm the immediate cause of death, i.e. a gunshot wound to the head. Observations of the physical anthropologist concerning the good condition of the dead man's teeth are explained by his veterinary profession with a high social and material status.

The main result of the combined archaeological and ethnographic research reflection on the grave in question is thus the conclusion that the human remains found are the remains of a young veterinarian of German nationality, probably serving in the army, who was killed in Konstantynów. Thanks to this we were able to hand over the remains to the German War Graves Commission so that they could be buried with due respect in the Cemetery of German Soldiers established in 1998 in Siemianowice Śląskie. The wartime story of a German killed by Russians is so deeply rooted in the collective memory of Konstanstynów that even though the remains were exhumed, local inhabitants keep lighting candles in the place of his burial and call him 'our German'.

The above example of ethnoarchaeological research in the Polish Jurassic Highland can create a false impression that ethnoarchaeology is just one of many sciences and methods supporting archaeology of the contemporary past. One could not be more wrong! Defining archaeology of the contemporary past as archaeology of us should point researchers towards ethnographic research into community and the community understanding of its heritage. Ethnoarchaeology, applied within archaeology of the contemporary past, should become a platform for interdisciplinary research that takes into consideration a wide array of concepts and methods, both from the shared ethnographic and archaeological perspective, and from separate perspectives: the ethnographic one and the archaeological one. In order to make it happen, it is necessary to form ethnographic and archaeological interdisciplinary teams, which is difficult as it requires overcoming many structural, methodological and administrative problems as well as stereotypes created over the years by specialists in both fields. This, however, is a completely different issue. 


\section{Bibliography}

Archeologia sądowa w teorii i praktyce (2013), Ł. Trzciński (ed.), Wolters Kluwer Polska SA, Warszawa.

Archeologia totalitaryzmu. Ślady represji 1939-1956 (2015), O. Ławrynowicz, J. Żelazko (ed.), Instytut Archeologii Uniwersytetu Łódzkiego; Instytut Pamięci Narodowej, Komisja Ścigania Zbrodni przeciwko Narodowi Polskiemu Oddział w Łodzi, Łódź.

Buchli V., Lucas G. (2001a), The Absent Present: Archaeologies of the Contemporary Past, [in:] V. Buchli, G. Lucas (ed.), Archaeologies of the Contemporary Past, Routledge,

New York, p. 3-18, https://doi.org/10.4324/9780203185100

Buchli V., Lucas G. (2001b), Between Remembering and Forgetting, [in:]

V. Buchli, G. Lucas (ed.), Archaeologies of the Contemporary Past, Routledge,

New York, p. 79-83, https://doi.org/10.4324/9780203185100

Edensor T. (2005), Industrial Ruins. Space, Aesthetics and Materiality, Berg Publishers, Oxford. González-Ruibal A. (2014), Archaeology of the Contemporary Past, [in:] C. Smith (ed.),

Encyclopedia of Global Archaeology, Springer, New York, p. 1683-1694, https://doi. org/10.1007/978-1-4419-0465-2_1320

Harrison R., Schofield J. (2010), After Modernity. Archaeological Approaches to the

Contemporary Past, Oxford University Press, Oxford.

Holtorf C. (2014), Time for Archaeology! A Personal Portfolio of Fieldwork, [in:]

H. Alexandersson, A. Andreeff, A. Bünz (ed.), Med hjärta och hjärna. En vänbok till professor Elisabeth Arwill-Nordbladh, Universtity of Göteborg, Göteborg, p. 51-64.

Kajda K. (2016), Mam już dość prostej martyrologii. W stronę humanistyki afirmatywnej, "Biografia Archeologii", 2 (2), p. 4-11.

Kajzer L. (1996), Wstęp do archeologii historycznej, Wydawnictwo Uniwersytetu Łódzkiego, Łódź.

Kajzer L. (2013), Some Remarks about Historical Archaeology in Poland, [in:] N. Mehler (ed.), Historical Archaeology in Central Europe, Society for Historical Archaeology, Rockville, p. 95-101.

Kobiałka D. (2016), UrbEx: archeologiczny flâneuryzm a multitemporalność dziedzictwa, "Biografia Archeologii", 2 (1), p. 3-12.

Kobiałka D. (2017), Kufer peten wspomnień: (auto)biograficzne podejście do dziedzictwa, "Acta Universitatis Lodziensis. Folia Archaeologica", 32, p. 191-213, https://doi. org/10.18778/0208-6034.32.08

Kobyliński Z. (2012), Etnoarcheologia, [in:] P. Tabaczyński, A. Marciniak, D. Cyngot, A. Zalewska (ed.), Przeszłość spoteczna. Próba konceptualizacji, Wydawnictwo Poznańskie, Poznań, p. 721-731.

Krupa-Ławrynowicz A., Ławrynowicz O. (2012), Wyrzucana codzienność. Antropolog $z$ archeologiem rozmawiają o śmieciach, [in:] K. Łeńska-Bąk, M. Sztandara (ed.), 
Stromata Anthropologica, vol. VIII, Brud. Dylematy - idee - sprawy, Wydawnictwo Uniwersytetu Opolskiego, Opole 2012, p. 139-154.

Krupa-Ławrynowicz A., Ławrynowicz O. (2016), O projekcie, [in:] A.P. Wejland, O. Ławrynowicz (ed.), Miejsca pamięci i miejsca zapomnienia. Interdyscyplinarne badania na Jurze Krakowsko-Częstochowskiej. Raport z badań, vol. I, Wprowadzenie metodologiczne, Instytut Archeologii Uniwersytetu Łódzkiego, Łódź, p. 8-18.

Krupa-Ławrynowicz A., Ławrynowicz O. (2017), „Nasz Niemiec” z Konstantynowa. Historia - pamięć - miejsce, [in:] M. Skrzypczyk (ed.), Krajobrazy kulturowe ziemi lelowskiej, Lelowskie Towarzystwo Historyczno-Kulturalne, Urząd Gminy Lelów, Lelów, p. 183-208.

Ławrynowicz O. (2016), Metodyka diagnozy archeologicznej, [in:] A.P. Wejland, O. Ławrynowicz (ed.), Miejsca pamięci i miejsca zapomnienia. Interdyscyplinarne badania na Jurze Krakowsko-Częstochowskiej. Raport z badań, vol. I, Wprowadzenie metodologiczne, Instytut Archeologii Uniwersytetu Łódzkiego, Łódź, p. 90-107. Matériel Culture. The Archaeology of Twentieth-Century Conflict (One World Archaeology) (2012), C.M. Beck, W.G. Johnson, J. Schofield (ed.), Routledge, New York. Modern Material Culture. The Archaeology of Us (1981), R.A. Gould, M.B. Schiffer (ed.), Academic Press, Cambridge.

Moshenska G. (2013), The Archaeology of the Second World War. Uncovering Britain's Wartime Heritage, Pen \& Sword Archaeology, Barnsley.

Pawleta M. (2016), Przesztość we wspótczesności. Studium metodologiczne archeologicznie kreowanej przesztości w przestrzeni spotecznej, Wydawnictwo Naukowe UAM, Poznań. Places in Mind. Public Archaeology as Applied Anthropology (2004), P.A. Shackel, E.J. Chambers (ed.), Routledge, New York-London.

Prinke A. (1973), Możliwości porównawczego stosowania danych etnograficznych $w$ archeologii, "Etnografia Polska", 17 (1), p. 41-65.

Pufendorf S. (1696), De Rebus a Carolo Gustavo Sveciae Rege Gestis Commentariorum Libri Septem Elegantissimis Tabulis Aeneis Exornati cum Triplici Indice, Sumptibus Christophori Riegelli Literis Knorzianis, Norimbergae.

Rathje W.L. (1984), The Garbage Decade, "American Behavioral Scientist", 28 (1), p. 9-29, https://doi.org/10.1177/000276484028001003

Rathje W.L., Murphy C. (2001), Rubbish! The Archaeology of Garbage, University of Arizona Press, Tucscon.

Saunders N.J. (2007), Killing Time. Archaeology and the First World War, Stroud, Sutton. Shackel P.A. (2003), Archaeology, Memory, and Landscapes of Conflict, "Historical Archaeology”, 37 (3), p. 3-13, https://doi.org/10.1007/BF03376607

Tully G. (2007), Community Archaeology. General Methods and Standards of Practice, "Public Archaeology", 6 (3), p. 155-187, https://doi. org/10.1179/175355307X243645 
Wejland A.P. (2016a), Pojęcia podstawowe, [in:] A.P. Wejland, O. Ławrynowicz (ed.), Miejsca pamięci i miejsca zapomnienia. Interdyscyplinarne badania na Jurze Krakowsko-Czestochowskiej. Raport z badań, vol. I, Wprowadzenie metodologiczne, Instytut Archeologii Uniwersytetu Łódzkiego, Łódź, p. 38-50.

Wejland A.P. (2016b), Metodyka diagnozy etnograficznej, [in:] A.P. Wejland, O. Ławrynowicz (ed.), Miejsca pamięci i miejsca zapomnienia. Interdyscyplinarne badania na Jurze Krakowsko-Czestochowskiej. Raport z badań, vol. I, Wprowadzenie metodologiczne, Instytut Archeologii Uniwersytetu Łódzkiego, Łódź, p. 59-89.

Wejland A.P. (2016c), Strategia badawcza, [in:] A.P. Wejland, O. Ławrynowicz (ed.), Miejsca pamięci i miejsca zapomnienia. Interdyscyplinarne badania na Jurze Krakowsko-Częstochowskiej. Raportz badań, vol. I, Wprowadzenie metodologiczne, Instytut Archeologii Uniwersytetu Łódzkiego, Łódź, p. 51-57.

Zalewska A.I. (2014), Prospoteczna, partycypacyjna i „wspólnotowa” archeologia bliskiej przesztości, "Studia Humanistyczne AGH”, 13 (2), p. 19-38, https://doi. org/10.7494/human.2014.13.2.19

Zalewska A.I. (2016a), Archeologia czasów wspótczesnych w Polsce. Tu i teraz, [in:] A.I. Zalewska (ed.), Archeologia wspótczesności. Pierwszy Kongres Archeologii Polskiej, vol. I, Stowarzyszenie Naukowe Archeologów Polskich, Warszawa, p. 21-39.

Zalewska A.I. (2016b), Archeologia wspótczesnych konfliktów zbrojnych jako praktykowanie prospotecznej archeologii. Przyktad wartości epistemologicznej i aksjologicznej, [in:] A.I. Zalewska (ed.), Archeologia wspótczesności. Pierwszy Kongres Archeologii Polskiej, vol. I, Stowarzyszenie Naukowe Archeologów Polskich, Warszawa, p. 125-140.

\section{Summary}

\section{Archaeology of Us and the Local Identity. An Interdisciplinary Context}

In this paper, the Author presents the semantic and methodological scope and characteristics of a new field the archaeology of the contemporary past. In his opinion the essence of the archaeology of the contemporary past is best conveyed by the term archaeology of us, which refers to the relationships between individuals or communities and their own material heritage. Due to the community and local dimension of archaeology of the contemporary past, an important source in this field is oral tradition, which is obtained and analysed during ethnographic interviews. The author refers to his own experience, gained during many years of research in the Polish Jurassic Highland, and indicates the importance and research effectiveness of incorporating the methodology of ethnographic research into the perspective of archaeology of the contemporary past. 
Keywords: archaeology of us, archaeology of the contemporary past, ethnoarchaeological research, interdisciplinary research, Polish Jurassic Highland

\section{Streszczenie}

\section{Archeologia nas a tożsamość lokalna. Kontekst interdyscyplinarny}

Autor w artykule przedstawia zakresy znaczeniowe i metodologiczne nowej specjalizacji, jaką jest archeologia współczesności, wykazując podstawowe cechy ją charakteryzujące. Uważa, że istotę archeologii współczesności najlepiej oddaje pojęcie archeologia nas (archaeology of us), odnoszące się do relacji konkretnych ludzi i wspólnot z ich własnym dziedzictwem materialnym. Wspólnotowy i lokalny wymiar archeologii współczesności powoduje, że ważnym dla niej źródłem są przekazy ustne, pozyskiwane i analizowane w trakcie wywiadów etnograficznych. Autor powołuje się na własne doświadczenia, przede wszystkim wieloletnich badań na Jurze Krakowsko-Częstochowskiej, i wskazuje, jak ważne i badawczo efektywne może być włączanie w perspektywę archeologii współczesności metodologii badań etnograficznych.

Słowa kluczowe: archeologia nas, archeologia współczesności, badania etnoarcheologiczne, badania interdyscyplinarne, Jura Krakowsko-Częstochowska

Research funded under a programme of the Minister of Science and Higher Education "National Programme for the Development of Humanities" in 20I4-20I9. 